\title{
Translation used in Learning and Teaching Method for Elementary School Students in Indonesia
}

\author{
Karnain $^{1}$, Ana Purwitasari² \\ ${ }^{1}$ SD Negeri Sidamukti II (Elementary School Teacher), Indonesia \\ E-mail: nana.karnain65@gmail.com \\ ${ }^{2}$ Freiburg Institute for Advanced Studies, University of Freiburg, Germany \\ E-mail: ana.purwitasari93@gmail.com
}

\begin{abstract}
The pluralism existing in Indonesia contributes to use of translation strategies during learning and teaching process. In Majalengka, for instance, as one of regions separating two local languages in West Java where the study is conducted teachers tend to use both Indonesian and Sundanese or Javanese depending on the districts from where their students come. The examination results in the conclusions that loanword, paraphrasing, literal translation, functional equivalent, descriptive equivalent, and reducing of some elements are the most used translation method in leaming and teaching process. As this study focuses on elementary school in Majalengka, the students are respectively involved as the respondents. After the six-month period inquiry in sub district of Majalengkaby recording the learning and teaching process in elementary schools in Majalengka, it could clearly concluded that translation is the most effective method to help students from region where pluralism exists to understand the foreign terms without using the dictionary. Keywords - elementary school, indonesia, learning and teaching method, pluralism, translation.
\end{abstract}

\section{INTRODUCTION}

The main question addressed in this exploration is the translation strategies the teachers use to teach their students in elementary school level. Majalengka as one of regencies in West Java is meticulously chosen as the place where this study took place based on the previous work carried out by Purwitasari (2018a) which declared that Majalengka separates Sundanese and Javanese as two most widely spoken local languages in Indonesia. Moreover, she stated that some linguistic variations, even Javanese enclave, are doubtless found in Majalengka although it lies in West Java as home for Sundanese speakers. This statement is strengthened by another research which informs that students of elementary school level in sub district of Majalengka-one of sub districts in the regency of Majalengka- speak Sundanese both in rude and polite styles and Indonesian, instead of Javanese as it is far from Javanese enclave (Purwitasari, 2018b). It means that two languages, e.g. Sundanese and Indonesian, are obviously spoken by the students to communicate with the teachers and other students as well.

Linguistic convergence found during learning and teaching process in elementary schools in sub district of Majalengka leads to this investigation as one of studies in applied linguistics which connects linguistic and translation. The status of Indonesian as educational language forces the students of educational levels in Indonesia to use and speak Indonesian correctly. Since the students of elementary school in sub district of Majalengka are mostly native speakers of Sundanese, they attempt to manage to learn Indonesian in school properly. Therefore, when there is one term in Indonesian which they do not understand, the teachers should transfer its meaning to Sundanese.

Since the scope of this inquiry is not limited to foreign language teaching, but other subjects as well, there are usually two stages of translation, including translating the meaning into Sundanese and explaining the meaning using detailed description. For instance, the term akselerasi 'accelerate' in the class of Bahasa Indonesia 'Indonesian' and IPA 'science'. Although that word is in Indonesian, it should be commonly simplified in order to be understood by the students. The first step is transferring it into the words which have the simplest meaning, e.g. percepatan 'quicken' and penambahan 'increase'. Then, the teacher describes that akselerasi is used referring to becoming more quickly or increasing in amount or scale. This process is called translation strategy that involves both translation method and translation procedure (Fani\&Rahmawati, 2015:92).

Translation strategies encourage the teachers to use some patterns in transferring foreign words during learning and teaching process. Those terms refer to at least loanword, paraphrase, synonym, cultural equivalent, literal trans lation, functional equivalent, descriptive equivalent, and reduction 
as stated by Newmark (in Munday, 2008:44-45). There are typically 15 strategies of trans lation according to Newmark, including transference or loanword, naturalization, cultural equivalent, functional equivalent, descriptive equivalent, synonym, through-translation, transposition, modulation, recognized translation, reduction, paraphrase, compensation, contextual conditioning, and couplets .

Transference or loanword is the translation without any changes existing in TL. It means, words in source language (SL) is still written as foreign word in target language (TL). However, naturalization changes the spelling of words in $\mathrm{SL}$ in order to be grammatically and phonetically readable in TL. For example, the word hygienic in English is pronounced as higienis in Indonesian.

The two procedures written above differ from cultural equivalent which refers to transferring the words influenced by cultural environment both in SL and TL due to the opinion claimed by Sapir that there are no two languages and two cultures that can be surely characterized as the same to tell something (in Stolze, 2008:30). Functional equivalent is the procedure that translates a word by describing the word freely, instead of depending on grammatical rule in TL. However, functional equivalent contrasts strikingly with descriptive equivalent that transfers the meaning of word from SL to TL by describing it depending on specific characteristics the word has.

Synonym is used to translate by using the near context from SL into TL. On the contrary, through-translation is defined as literal translation. Transposition procedure pays more attention to grammaticalchange while transferring the word or expression from SL to TL. The reverse concept of through-translation is modulation which is used to change the perspective.

Recognized translation is the translation of institutional term. Reduction is the procedure with elimination or addition of some existing elements in TL which is distinct from paraphrasing which is closely related to translation of any segments in SL. The compensation procedure is the loss of meaning or prag matic effect. When the translator add several words is called as contextual conditioning procedure. Furthermore, the combination of two translation procedures is defined as couplets.

\section{METHOD}

The method used in this analysis is recording the learning and teaching process within six-month period. To begin with, the first phase to gather the data was expounded. Firstly, the learning and teaching process in every class is specifically observed, started in class I, II, and III considering the fact that students from the low and upper-educational level have divergent level of vocabulary mastery. As the scope is focused on translation, the authors of this paper carried out the research in Bahasa Indonesia class for having texts on the reference books, such as BukuTematikTerpaduKurikulum 2013 Tema 1 Kelas 1 Diriku, BukuTematikTerpaduKurikulum 2013 Tema 2 Kelas 1 Kegemaranku, BukuTematikTerpaduKurikulum 2013 Tema 3 Kelas 1 Kegiatanku, BukuTematikTerpaduKurikulum 2013 Tema 4 Kelas 1 Keluargaku, Buku Sang Petualang 2 Bahasa Indonesia, and Buku BinaBahasadanSastra Indonesia UntukSekolahDasarKelas 3.

Analysis of each translation strategy comes as upcoming stage in this investigation. First of all, the authors of this paper write down the products of translation process based on what have been clearly recorded and written in the reference books. Later step is to compile the data before analysis process. Then, they are categorized according to translation theory conveyed by Newmark.

\section{RESULTS}

In general, there are six translation strategies which were respectively used during the learning and teaching process in the class of I, II, and III in Bahasa Indonesia class. They are loanword, paraphrase, literal translation, functional equivalent, descriptive equivalent, and reduction of some elements. Bahasa Indonesia or Indonesian is the source language (SL) for being educational language, whereas BahasaSunda or Sundanese is the target language (TL) for being language spoken natively by most of students in this examination. The result of this inquiry is presented as follow.

Foreign word:

27nus okbilangan (Indonesian) 'number'

Explanation by teacher:

nomer (Sundanese) 'number'

Translation strategy: literal translation

Reference: BukuTematikTerpaduKurikulum

2013 Tema 1 Kelas 1 Diriku, page 23

2 Foreign word:

keliru (Indonesian) 'wrong'

Explanation by teacher:

salah (Sundanese) 'wrong'

Translation strategy: literal translation

Reference: BukuTematikTerpaduKurikulu m

2013 Tema 1 Kelas 1 Diriku, page 44

3 Foreign word:

pancaindra (Indonesian) 'the five human senses'

Explanation by teacher:

Panon, lètah, pangambung, cepil, sarengkulitnaminapancaindera. (Sundanese)

'Eyes, tongue, nose, ears, and skin are categorized as the five human senses.'

Translation strategy: descriptive equivalent 
Reference: BukuTematikTerpaduKurikulum

2013 Tema 1 Kelas 1 Diriku, page 49

4

Foreign word:

mengamati (Indonesian) 'investigate'

Explanation by teacher:

nengetan (Sundanese) 'investigate'

Translation strategy: literal translation

Refernce: BukuTematikTerpaduKurikulum

2013 Tema 1 Kelas 1 Diriku, page 52

5

Foreign word:

karya (Indonesian)'art work'

Explanation by teacher:

Naon-naonwaeanudihasilkeunkukreativitasur ang. (Sundanese)

'Everything created based on our skills.'

Translation strategy: functional equivalent

Reference: BukuTematikTerpaduKurikulum

2013 Tema 1 Kelas 1 Diriku, page 75

Foreign word:

ber-fluoride (Indonesian) 'containing fluoride'

Explanation by teacher:

aya fluoride-an (Sundanese) 'containing

fluoride'

Translation strategy: literal translation

Reference: BukuTematikTerpaduKurikulu m

2013 Tema 1 Kelas 1 Diriku, page 93

Foreign word:

menghargai (Indonesian) 'have respect for something'

Explanation by teacher:

ngahormatan (Sundanese) 'have respect for something'

Translation strategy: literal translation

Reference: BukuTematikTerpaduKurikulum

2013 Tema 1 Kelas 1 Diriku, page 115

Foreign word:

memaklumi

(Indonesian)

'being

understandable'

Explanation by teacher:

ngamaklum 'being

understandable'

Translation strategy: literal translation

Reference: BukuTematikTerpaduKurikulum

2013 Tema 1 Kelas 1 Diriku, page 115

Foreign word:

rahmat (Indonesian) 'gift from God'

Explanation by teacher:

PamasihanGusti Allah (Sundanese)

'something given by God'

Translation strategy: paraphrase

Reference: BukuTematikTerpaduKurikulum

2013 Tema 1 Kelas 1 Diriku, page 116

10

Foreign sentence:
SikapberjalanUdindanSiti

paling

lenturdanseimbang. (Indonesian)

'Udin and Siti can walk properly.'

Explanation by teacher:

UdinjeungSitileumpangnabener. (Sundanese)

'Udin and Siti can walk properly.'

Translation strategy: functional equivalent

Reference: BukuTematikTerpaduKurikulum

2013 Tema 1 Kelas 1 Diriku, page 131

11 Foreign sentence:

Dayuberbagimelaluikelebihan

yang

dimilikinya. (Indonesian)

'Dayu shares with each other through her specialty.'

Explanation by teacher:

Dayuteupelitngabagikalebihannajeungbabatu

ranna. (Sundanese)

'Dayu shares willingly her specialty with each other.'

Translation strategy: paraphrase

Reference: BukuTematikTerpaduKurikulum

2013 Tema 1 Kelas 1 Diriku, page 133

12 Foreign sentence:

Menceritakankebersamaandalamkeberagama

$n$ di rumah. (Indonesian)

'Telling about the story of togetherness among diversity at home.'

Explanation by teacher:

Nyaritakeunnaon-naonwae nu sarua di imahnajanaya nu bedana. (Sundanese)

'Telling about everything same although diversity found at home.'

Translation strategy: paraphrase

Reference: BukuTematikTerpaduKurikulum

2013 Tema 1 Kelas 1 Diriku, page 146

13 Foreign word:

simpai (Indonesian) 'hula-hoop'

Explanation by teacher:

hula-hoop (Sundanese) 'hula-hoop'

Translation strategy: loanword or transference

Reference: BukuTematikTerpaduKurikulu m

2013 Tema 2 Kelas 1 Kegemaranku, page 34

14 Foreign phrase:

Menangismeraung-raung (Indonesian) 'crying loudly'

Explanation by teacher:

Ceurikgagauran (Sundanese) 'crying loudly'

Translation strategy: literal translation

Reference: BukuTematikTerpaduKurikulum

2013 Tema 2 Kelas 1 Kegemaranku, page 51

15 Foreign phrase:

Syairlagu (Indonesian) 'song lyric'

Explanation by teacher: 
Liriklagu (Sundanese) 'song lyric'

Translation strategy: literal translation

Reference: BukuTematikTerpaduKurikulum

2013 Tema 2 Kelas 1 Kegemaranku, page 60

16

Foreign word:

siamang (Indonesian) 'primate'

Explanation by teacher:

29nus ok (Sundanese) 'primate'

Translation strategy: loanword or transference

Reference: BukuTematikTerpaduKurikulum

2013 Tema 2 Kelas 1 Kegemaranku, page 90

17 Foreign word:

kolase (Indonesian) 'collage'

Explanation by teacher:

Tempatjangkumpulanpotoatanapibaranganuи

nik (Sundanese) 'place to show collection of

photos or unique stuffs'

Translation strategy: functional equivalent

Reference: BukuTematikTerpaduKurikulum

2013 Tema 2 Kelas 1 Kegemaranku, page 137

Foreign phrase:

Supayadapatmengamalkannya. (Indonesian)

'in order to act as its expected'

Explanation by teacher:

Sangkan 29 nusngamalkeunnana. (Sundanese)

'in order to act as its expected'

Translatation strategy: literal translation

Reference: BukuTematikTerpaduKurikulum

2013 Tema 3 Kelas 1 Kegiatanku, page 6

Foreign phrase:

SilaPancasila (Indonesian) 'principles of

Pancasila'

Explanation by teacher:

PoinanujadipokokutamaPancasila

(Sundanese) 'the main point of Pancasila as the

basic philosophy of Indonesia'

Translation strategy: functional equivalent

Reference: BukuTematikTerpaduKurikulu m

2013 Tema 3 Kelas 1 Kegiatanku, page 12

Foreign phrase:

kertas origami (Indonesian) 'origami paper'

Explanation by teacher:

kertaspikeunnyieunkaryaseni

(Sundanese)

'paper used to make art work'

Translation strategy: functional equivalent

Reference: BukuTematikTerpaduKurikulu m

2013 Tema 3 Kelas 1 Kegiatanku, page 93

21

Foreign word:

Petualang (Indonesian) 'traveller'

Explanation by teacher:

nu sokpelesirkaunggaltempat (Sundanese) 'the person who always travels everywhere'

Translation strategy: paraphrase
Reference: Buku Sang Petualang 2 Bahasa

Indonesia, page 15

22 Foreign phrase:

secepatkilat (Indonesian) 'very quickly'

Explanation by teacher:

gancangpisan (Sundanese) 'very quickly'

Translation strategy: literal translation

Reference: BukuBinaBahasadanSastra

Indonesia UntukSeko lahDasarKe las 3, page 39

23 Foreign phrase:

laritunggang-langgang (Indonesian) 'run very quickly'

Explanation by teacher:

lumpatsatarikna (Sundanese) 'run very quickly'

Translation strategy: literal translation

Reference: BukuBinaBahasadanSastra

Indonesia UntukSekolahDasarKelas 3, page 50

24 Foreign word:

dangau (Indonesian) 'a little cabin in the forest'

Explanation by teacher:

saung (Sundanese) 'a little cabin in the forest'

Translation strategy: literal translation

Reference: BukuBinaBahasadanSastra

Indonesia UntukSeko lahDasarKelas 3, page 92

25 Foreign sentence:

Akhirnyamerekaberdebat. (Indonesian)

'finally, they argue'

Explanation by teacher:

Tungtungnamahkalahpaséa(Sundanese)

'finally, they argue'

Translation strategy: reduction of some element

Reference: BukuBinaBahasadanSastra

Indonesia UntukSekolahDasarKelas 3, page 120

\section{DISCUSSION}

This short-term investigation is based on the relationship between language, linguistic, and translation. Language is the tool of communication. Therefore, being able to speak more than one language fluently which is deepened by theories of translation, helps somebody to transfer the meaning of words in one language to the others. As the result, translation strengthens the theory about linguistics as the scientific study of language.

At some time, research about translation is excluded from the branch of linguistics. The fact shows that translation is the part of applied linguistics. Translation used in learning and teaching process remains avoidable to be conducted due to limitation of research area. Studies related to translation are including translation used by teachers to 
transfer the knowledge to their students. This leads to a suggestion to carry out other investigations about translation and applied linguistics, especially language use in a class at every educational level in Indonesia as multicultural country.

\section{CONCLUSION}

The high average of students who attend elementary schools in sub district of Majalengka who are willingly capable of having competence on multilingualism support teachers to use translation during learning and teaching process. In order to make the students as part of bilingual community who speak both Sundanese as first language and Indonesian as national language used in educational institutions, understand,teachers tend to simplify each of foreign words. The translation strategies that they use are loanword or transference, paraphrase, literal translation, functional equivalent, descriptive equivalent, and reduction of some elements. Thus, the students do not need dictionary of each subject. To this point, both teachers and students involving in this learning and teaching process can surely solve the problem since there are still ele mentary schools in Majalengka which are not able to facilitate their students correctly, including providing dictionaries of each subjects to accompany students while they are learning.

\section{REFERENCES}

[1] Adellina, N., Yun Kusumawati, LubnaAssagaf. (2018). Buku Tematik Terpadu Kurikulum 2013 Tema 1 Kelas 1 Diriku. Bandung: PT. SaranaPancakarya Nusa.

[2] Adellina, N., Yun Kusumawati, LubnaAssagaf. (2018). Buku TematikT erpadu Kurikulum 2013 Tema 2 Kelas 1 Kegemaranku. Bandung: PT. SaranaPancakarya Nusa.

[3] Adellina, N., Yun Kusumawati, LubnaAssagaf. (2018). Buku Tematik Terpadu Kurikulum 2013 Tema 3 Kelas 1 Kegiatanku. Bandung: PT. SaranaPancakarya Nusa.

[4] Adellina, N., Yun Kusumawati, LubnaAssagaf. (2018). Buku Tematik Terpadu Kurikulum 2013 Tema 4 Kelas 1 Keluargaku. Bandung: PT. SaranaPancakarya Nusa.

[5] Fani, M.C. Rahmawati, S. (2015). The Translation Strategies in "Kung Fu Panda" Animation Movie.The $5^{\text {th }}$ Atma Jaya International Conference in Translation \& Interpretation Studies, pp.91-94.

[6] Munday, J. (2008). Introducing Translation Studies Theories and applications. London and New York: Routledge Taylor \& Francis Group.

[7] Purwitasari, A. 2018a. Language map in the bordering region of two Malayo-Polynesian languages.
International Journal of Advanced Research, 6(4), pp. 577-580. DOI: $\quad$ 10.21474/IJAR01/6843.

[8] Purwitasari, A. 2018b. Language Use in Elementary Schools in Majalengka (Indonesia). International Journal of Education and Social Science Research, 1(5), pp. 81-93.

[9] Rafiah, D. F., MeichatiCandra D., Retno W. H., (2010). Sang Petualang 2. Jakarta: Pusat Perbukuan Kementerian Pendidikan Nasional.

[10] Stolze,

$\mathrm{R}$.

(2008).

ÜbersetzungstheorienEineEinführung. Tübingen: Narr Francke Attempto Verlag.

[11] Yusuf, S., Purwati, Asep Effendi, Aswan, Sanusi Budi, Uripasih. (2004). Bina Bahasadan Sastra Indonesia. Jakarta: PenerbitErlangga. 